\title{
Socio-Economic Impact of Microfinance on the SHGS Members Engaged in Agriculture and Allied Enterprises
}

\author{
R. G. Nair* ${ }^{*}$ R. P. Kadam and P. S. Kapse \\ Department of Extension Education, Vasantrao Naik Marathwada Krishi Vidyapeeth, \\ Parbhani, M.S., India \\ *Corresponding author
}

\section{Keywords}

Socio-economic impact of microfinance, SHGs (Self Help Groups), SHGs members

Article Info

Accepted:

22 April 2021

Available Online:

10 May 2021

A B S T R A C T

\section{Introduction}

Socio-economic impact assessment focuses on evaluating the impacts development has on community social and economic well-being. This analysis relies on both quantitative and qualitative measures impacts. Development impacts are generally evaluated in terms of changes in community demographics, housing, employment and income, market effects, public services, and aesthetic qualities of the community. Qualitative assessment of community perceptions about development is an equally important measure of development impacts. Assessing proposed developments in a socio-economic context will help community leaders and residents identify potential social equity issues, evaluate the adequacy of social services and determine whether the project or scheme may adversely affects overall social well-being in terms of demographics, housing, employment and income, public services, retail business analysis, quality of life and aesthetics. (Edwards 2000). Therefore the present study includes evaluating the impact development of 
microfinance on the members of self help groups for social and economic well-being. For assessing the impact of microfinance, comparison was made between before and after situation in SHG of the respondents. The information on various social and economic aspects, such as behaviour, social status, annual expenditure pattern, assets, income, borrowing, employment status and monthly thrift habit was collected to assess the impact.

Government is showing special interest to organize rural poor that is small farmers, marginal farmers and agricultural labours into SHGs. This is reflected in Swarnajayanti Gram Swarojgar Yojana (SGSY). Under this programme usually, the focus is on poor and that too on women.

The women groups have proved that they would indeed bring about a change in the mindset of the very conservative and tradition bound illiterate women in rural areas.

Normally, it is found that initially though the groups are pursuing an economic activity; gradually they diversify and take up more than one development activity in the area. SHGs are promoting saving and credit along with other income generating activities.

Participation in SHGs is likely to influence positively the adoption of agricultural technologies by the members. This would bring socio-economic change among members and thereby, would raise their standard of living. In addition, group approach enables for flow of formal credit, collective action and problem solving.

In this context, it becomes imperative to understand impact of micro financing on the members of SHGs engaged in agriculture and allied enterprises in a holistic way. Whether such activities are judiciously integrated with the existing farming systems or viewed in isolation and whether some of the constraints faced by the members, could be addressed by group approach in a social context, wherein group mobilization and flow of credit to invest in micro enterprises is present.

\section{Materials and Methods}

For the present study out of eight districts of Marathwada region of Maharashtra state two districts were purposively selected i.e. Nanded and Parbhani based on maximum number of self help groups during the years 2019-20 in jurisdiction of Mahila Arthic Vikas Mahamandal Organization (MAVIM) and District Rural Development Agency (DRDA) in Marathwada region of Maharashtra state as significant work done by both MAVIM and DRDA in the formation of SHGs. Three talukas were purposively selected from each district for the present study on the basis of maximum numbers of self help groups. The selected talukas from Parbhani district were Parbhani, Purna and Gangakhed as well as from Nanded district the selected talukas were Kinwat, Nanded and Aardhapur these all talukas were selected on the basis of the maximum numbers of self help groups.

From each selected village 07 women members of self help group were selected randomly to make a sample of 35 women members of self help group from each selected talukas and the total 105 women members of self help groups from each district.

Thus, total to the tune of 210 women members of self help group were selected for present study from both the districts. Ex-post facto research design was adopted in this study. The data were collected with the help of pretested interview schedule. The statistical methods and tests such as frequency, percentage, mean, standard deviation, co-efficient of correlation, multiple regressions, $\mathrm{Z}$ test and path analysis were used for the analysis of data. 
The main objectives of this study to determine the socio- economic impact of microfinance on the SHGs members engaged in agriculture and allied enterprises.

\section{Results and Discussion}

\section{Determining of socio-economic impact of microfinance}

Therefore the present study includes evaluating the impact development of microfinance on the members of self help groups for social and economic well-being. For assessing the impact of microfinance, comparison was made between before and after situation in SHG of the respondents. The information on various social and economic aspects, such as behaviour, social status, annual expenditure pattern, assets, income, borrowing, employment status and monthly thrift habit was collected to assess the impact.

\section{Socio-economic impact of microfinance on the members of self help groups}

\section{Behavioural change}

It was found from the table 1 that, more than half $(65.71 \%)$ of the SHGs members had medium behavioural change categories, followed by 18.10 per cent of them in high and 16.19 per cent of them were in low behavioural change category before participation in SHGs.

After participation in SHGs, majority $(43.33 \%)$ of the SHGs members had in medium behavioural change categories, followed by 37.62 per cent of them in high and 19.05 per cent of them were in low behavioural change category. It is thus inferred that as a result of participation in SHGs, members had experienced remarkable behavioural change. Calculated ' $Z$ ' value 3.41 from table 1 was found significant at 1 per cent level of probability indicating that there existed a significant difference in behavioural change of SHGs members before and after participation in SHGs. It could therefore, be stated that the SHGs members differed significantly in behaviour before and after participation in SHGs.

As the behavioral changes occurred in SHG members after the participation were includes the risk-taking ability, ability for seeking knowledge regarding financial aspects, ability to solve their own problems, social decisionmaking ability of the members, ability to trust on SHG members, encouraged skills for selfsufficiency and awareness, ability to control own lives through personal decision making of life choices, leadership qualities among the members, increase self-confidence, courage and self-esteem and ability to develop positive attitude towards working independently.

It was observed from the table 2 that, after participation in SHGs, more than half $(59.52 \%)$ of SHGs members had medium behavioural change category, followed by 23.33 per cent of them were in low and 17.14 per cent of them had high behavioural change category. It was observed from above table that, most of the SHGs members having medium impact of microfinance on behavioural change.

The mean behavioural changes scores of before and after SHGs differed significantly with ' $Z$ ' value (3.41) at 1 per cent level of probability implying that there was an improvement in the behavioural nature of members of SHGs due to participation in SHGs. The mean behavioural changes of SHGs members before participation in SHGs and after participation in SHGs. It means that SHGs helpful the members of SHGs to improve in their behavioural nature. This shift of members of SHGs to improve behavioural nature after participation in SHGs might be 
due to the increase in information seeking behaviour.

The findings of the present are in conformity with the findings of Puhazhendi and Satyasai (2000), Yadav, et al., (2000) and Kulkarni (2003).

\section{Social status change}

It was observed from the table 3 that, majority (50.84\%) of the SHGs members had medium social status change categories, followed by 33.33 per cent of them in low and 19.05 per cent of them were in high social status change category before participation in SHGs.

After participation in SHGs, majority $(42.38 \%)$ of the SHGs members had medium social status change categories, followed by 31.43 per cent of them in high and 26.19 per cent of them were in low social status change category. This shift of members of SHGs to additional social status change of SHGs members. It was observed from the above table that, drastic social status changes observed after participation in SHGs.

Calculated ' $Z$ ' value 3.36 from table 3 was found significant at 1 per cent level of probability indicating that there existed a significant difference in social status change of SHGs members before and after participation in SHGs. It could therefore; it was observed that the SHGs members differed significantly in their social status before and after participation in SHGs.

After the participation, the SHGs members found to be changed social status as it was helped to develop the social network in the community, built up the sense of dignity, established sustainability and cohesiv eness among the members, access to credit helped to increase the livelihood security and welfare of members, increased the proportion of SHG women members in social, political and educational institutes as well as increased the participation of SHGs members in social activities.

It was observed from the table 4 that, after participation in SHGs, majority $(47.14 \%)$ of SHGs members had medium social status change category, followed by 26.67 per cent of them were in high and 26.19 per cent of the SHGs members had low social status change category. It was observed from above table that, most of the SHGs members having medium impact of microfinance on social status change.

The mean social status changes scores of before and after participation in SHGs differed significantly with ' $Z$ ' value (3.36) at 1 per cent level of probability implying that there was an improvement in the social status of members of SHGs due to participation in SHGs. This shift of members of SHGs to additional social status change of SHGs members.

The findings of the present study are compatible with the findings of Puhazhendi and Satyasai (2000), Singh and Prasad (2000), Kulkarni (2003), Adsul (2004) and Yadav et al., (2000).

\section{Annual expenditure pattern}

It was observed from the table 5 that, more than half $(53.33 \%)$ of the SHGs members had medium annual expenditure pattern categories, followed by 29.52 per cent of them in low and 17.15 per cent of them were in high annual expenditure pattern category before participation in SHGs.

After participation in SHGs, majority (48.10\%) of the SHGs members had medium annual expenditure pattern categories, followed by 26.19 per cent of them in high and 25.71 per cent of them were in low annual expenditure pattern category. It could be 
concluded that, expenditure in term of the farm assets included in investment in land, implements and machinery, livestock etc. while home assets included expenditure on basic need facilities, alteration in home and extension of accommodation structure. After participation in SHGs, additional employment generated by SHGs had made significant changes in the annual per capita income of the SHGs members. It was observed from the above table that, drastic annual expenditure pattern observed after participation in SHGs.

Calculated ' $Z$ ' value 2.71 from table 5 was found significant at 1 per cent level of probability indicating that there existed a significant difference in annual expenditure pattern of SHGs members before and after participation in SHGs. It could therefore, be stated that the SHGs members differed significantly in their annual expenditure pattern before and after participation in SHGs. It means that SHGs it helpful to the members for maintain annual expenditure pattern.

After participation in SHGs the members found to be increased in better access to health facilities, gained better education for children of members, helped to fulfill the basic needs of the family, could expend more on consumption, increased the intake of nutritious food by the SHG members, could use the loans for food, education, minor house repairs, farming, trading, processing, health and other emergencies, SHG members could invest in new technology and farm inputs for higher productivity, increased the share of the family budget on recreational items, could purchase modern technology for agricultural and allied activities, could raise capital for farm expenditure as well as could make a proper budget for profitable enterprise by the SHG members.

It was observed from the table 6 that, after participation in SHGs, more than half $(52.86 \%)$ per cent of SHGs members had medium annual expenditure pattern category, followed by 24.29 per cent of them were in high and 22.86 per cent of the SHGs members had low annual expenditure pattern category. It was observed from above table that, most of the SHGs members having medium impact of microfinance on annual expenditure pattern.

The mean change in annual expenditure pattern scores of before and after SHGs differed significantly with ' $Z$ ' value (2.71) at 1 per cent level of probability implying that there was well maintenance in the annual expenditure pattern of SHGs members due to participation in SHGs. The mean annual expenditure pattern of members of SHGs before participation in SHGs and after participation in SHGs the mean annual expenditure pattern was maintained it means that SHGs helpful to the members of SHGs for increase their income. Change in annual expenditure pattern refers to change in spending in rupees on food, clothing, educational and living condition. This change was measured by comparing pre and postgroup situation. This shift of members of SHGs to maintain percentage of medium annual expenditure pattern after participation in SHGs might be due to the increase in employment.

The findings of the present study are compatible with the findings of Singh and Prasad (2000), Kulkarni (2003), Rewale (2003) and Adsul (2004).

\section{Change in assets}

It was observed from the table 7 that, more than two third $(66.67 \%)$ of the members of SHGs had in medium change in assets categories, followed by 20.95 per cent and 12.38 per cent of them were in low and high change in assets category respectively before participation in SHGs.

After participation of SHGs, more than half 
(56.67\%) of the members of SHGs had in medium saving pattern change categories and 24.29 per cent of them in high saving pattern change category and 19.05 per cent of the SHGs members from low saving pattern change category. It could be concluded that, before participation of SHGs total income of the members of SHGs was not enough to meet their basic needs and hence there was no scope for saving and sometimes they had to borrow to maintain their routing life. This shift of members of SHGs to increase saving pattern after participation of SHGs might be due to the increase in annual income and change in education of their children due to employment generation. It was observed from the above table that, drastic saving pattern changes observed after participation of SHGs.

Calculated ' $Z$ ' value 2.06 from table 7 was found significant at 5 per cent level of probability indicating that there existed a significant difference in saving pattern change of SHGs members before and after participation of SHGs. It could therefore, be stated that the SHGs members differed significantly in their annual income before and after participation of SHGs. It means that SHGs is helpful to the members of SHGs for increase their saving pattern.

By getting the regular microfinance after participating in SHGs the member's ownership towards productive assets and productive resources increased now a day.

Members were able to develop the infrastructure of their residences also purchased needful modern technology and implements, increased possessing ability over communicational aids as well as household aids.

It was observed from the table 8 that, after participation in SHGs majority (49.05\%) of SHGs members had medium saving pattern change category, followed by 26.67 per cent and 24.29 per cent of the SHGs members had high and low saving pattern change category, respectively. It was observed from above table that, most of the SHGs members having medium impact of microfinance on saving pattern change.

The mean saving pattern scores of before and after participation of SHGs differed significantly with ' $Z$ ' value (2.06) at 5 per cent level of probability implying that there was an improvement in the saving pattern of members of SHGs due to participation of SHGs. This shift of members of SHGs to increase saving pattern after participation in SHGs might be due to the increase in annual income and change in occupation due to SHGs.

The findings of the present study are in line with the findings of Puhazhendi and Satyasai (2000), Katole (2001) and Singh (2001).

\section{Change in annual income}

It was observed from the table 9 that, majority $(48.10 \%)$ of the SHGs members had in medium change in annual income categories, followed by 32.38 per cent and 19.52 per cent of them were in low and high change in annual income category respectively before participation in SHGs.

After participation in SHGs, more than two third $(65.24 \%)$ of the SHGs members had in medium change in annual income categories, followed by 22.38 per cent and 12.38 per cent of them were in high and low change in annual income category, respectively. It could be concluded that, before participation in SHGs, the main source of SHGs members from traditional crop cultivation like cereals, fodder etc. However, total income of the SHGs members was not enough to meet their basic needs and hence there was no scope for saving and sometimes they had to borrow to maintain their routine life. 
After participation in SHGs, additional employment generated by SHGs had made significant changes in the annual per capita income of the SHGs members. It was observed from the above table that, drastic annual income changes observed after participation in SHGs.

Calculated ' $Z$ ' value 2.69 from table 9 was found significant at 1 per cent level of probability indicating that there existed a significant difference in annual income change of SHGs members before and after participation in SHGs. It could therefore, be stated that the SHGs members differed significantly in their change in annual income before and after participation in SHGs. It means that SHGs helpful to the members of SHGs for increase their annual income.

After participating in the SHGs, the women members found to be improved in standard of living as they were getting economically improved so they were getting good education which leads to get improved their personal and socio-economical status. By engaged in household business they could build up the capital and could generate more marketable surplus as well as able to manage financial crisis.

It was observed from the table 10 that, after participation in SHGs, more than two third $(65.71 \%)$ of SHGs members had medium change in annual income category, followed by 20.00 per cent and 14.29 per cent of the members of SHGs had high and low change in annual income category, respectively. It was observed from above table that, most of the members of SHGs having medium impact of microfinance on change in annual income. The mean change in annual income scores of before and after participation in SHGs differed significantly with ' $Z$ ' value (2.69) at 1 per cent level of probability implying that there was an improvement in the change in annual income of members of SHGs due to participation in SHGs. It means that SHGs useful the SHGs members to increase their annual income. Thus, it can be concluded that microfinance had significant impact in increasing the income level of members of self help group.

The results of the study conducted by Puhazhendi (2000), Dahiya et al., (2001), Katole (2001), Mishra and Houssain (2001), Nedumara et al., (2001), Puhazhendi and Satyasai (2001), Singh (2001), Mohite (2003), Rewale (2003), Adsul (2004), Peerzade and Parande (2005), Gangaiah et al., (2006) and Topare (2006) are similar to the findings of the present study.

\section{Change in borrowing pattern}

It was observed from the table 11 that, more than half $(57.62 \%)$ of the members of SHGs had in medium change in borrowing pattern categories, followed by 34.29 per cent in low and 8.10 per cent of them were in high change in borrowing pattern category before participation in SHGs.

After participation in SHGs, nearly half $(50.48 \%)$ of the members of SHGs had in medium change in borrowing pattern categories, followed by 38.10 per cent and 11.42 per cent of them in from low and high change in borrowing pattern category, respectively. In borrowing pattern there was observed that before participation in SHGs, members of SHGs had lack of luxurious facility, assets like black and white T.V., Radio, Bullock cart, bicycle due to their low annual income but result showed that after participation in SHGs, there was change in their life like luxuries facility like colour T.V., electricity facility, livestock, mobile, motor cycle and their housing pattern which improve their standard of living of their life. This change of borrowing pattern of members of SHGs after participation in SHGs might be due to the increase in income of members of 
SHGs due to employment generation. It was observed from the above table that, drastic change in borrowing pattern observed after participation in SHGs.

Calculated ' $Z$ ' value 2.74 from table 11 was found significant at 1 per cent level of probability indicating that there existed a significant difference in change in borrowing pattern of SHGs members before and after participation in SHGs.

It could therefore, be stated that the SHGs members differed significantly in their change in borrowing pattern before and after participation in SHGs. It means that SHGs helpful to the members of SHGs for increase their change in borrowing pattern.

As the SHG members were getting regularly finance so they could confidently engage in income generating activities and could get more benefit through it. SHG members never in tensed because SHGs were providing timely microfinance at minimum rate of interest so it helped SHG members to utilize that credit into the business.

It was observed from the table 12 that, after participation in SHGs, majority (37.14\%) of members of SHGs had medium change in borrowing pattern category, followed by 35.24 per cent and 27.62 of the SHGs members had low and high change in borrowing pattern category respectively. It was observed from above table that, most of the SHGs members having medium impact of microfinance on change in borrowing pattern.

The mean borrowing pattern scores of before and after participation in SHGs differed significantly with ' $Z$ ' value (2.74) at 1 per cent level of probability implying that there was a change in the borrowing pattern of members of SHGs due to participation in SHGs. It means that, SHGs are helpful to the members of SHGs for change their borrowing pattern. Rural people urgently need small amount of loan on regular basis. Self help groups provide loan to them for meeting their daily needs. The members of self help group were asked whether they had taken loan for productive and / or domestic purposes. The data with respect to borrowing of loan by the members of SHG was collected to know the per cent change in borrowing. In borrowing pattern there was observed that before participation in SHGs, members of SHGs had back of luxurious facility, assets like black and white T.V., Radio, Bullock car, Bicycle due to their low annual income but result showed that after participation in SHGs was change in their life like luxuries facility like colour T.V., electricity facility, livestock, mobile, motor cycle and their housing pattern which improve their standard of living of their life. This change of borrowing pattern of members of SHGs after participation in SHGs might be due to the increase in income of members of SHGs due to occupation, employment generation.

The findings of the present study are in agreement with the findings of Puhazhendi and Satyasai (2001).

\section{Change in employment status}

It was observed from the table 13 that, majority $(43.33 \%)$ of the members of SHGs had in medium change in employment status categories, followed by 40.95 per cent and 15.72 per cent of them were in low and high change in employment status category, respectively before participation in SHGs.

After participation in SHGs, more than half $(53.81 \%)$ of the members of SHGs had in medium change in employment status categories, followed by 25.71 per cent and 20.48 per cent of them in from high and low change in employment status category, respectively. Easy access to credit provides opportunities for undertaking income- 
generating activities, as a result of which, the employment opportunities at the group level increase. Even the members of SHGs could take up a number of income generating activities due to the credit and support provided by their respective SHGs. It is thus, inferred that, the SHGs had an assured impact on their members in generating employment opportunities for them and thus contributed to the family income. It was observed from the above table that, drastic change in employment status observed after participation in SHGs.

Calculated ' $Z$ ' value 3.02 from table 13 was found significant at 1 per cent level of probability indicating that there existed a significant difference in change in employment status of members of SHGs before and after participation in SHGs. It could therefore, be stated that the SHGs members differed significantly in their change in employment status before and after participation in SHGs. It means that SHGs in helpful to the members of SHGs for increase their change in employment status.

As the other rural women by seeing the employed SHGs women members wish to stand on their own feet to earn their livelihood in the rural areas. There was increased the chance of getting the timely microfinance to start own business by the SHG members and could able to face the adverse condition. SHG members were been successful in portraying positive self-image as employment creators for inspiring others in the society by engaging in agricultural and allied activities in the rural areas. It was observed from the table 14 that, after participation in SHGs, more than half $(54.76 \%)$ of members of SHGs had medium change in employment status, category followed by 25.24 per cent and 20.00 per cent of the SHGs members had high and low change in employment status category. It was observed from above table that, most of the
SHGs members having medium impact of microfinance on change in employment status.

The mean change in employment status scores of before and after participation in SHGs differed significantly with ' $Z$ ' value (3.02) at 1 per cent level of probability implying that there was normally improvement in the employment status of members of SHGs due to participation in SHGs. This shift of SHGs members is due to participation in different income-generating activities.

The findings are well supported by the research findings of Puhazhendi (2000), Katole (2001), Mishra and Houssain (2001), Puhazhendi and Satyasai (2001), Sarker (2001), Mohite (2003), Rewale (2003), Adsul (2004), Gangaiah et al., (2006) and Topare (2006).

\section{Monthly thrift habit}

It was observed from the table 15 that, more than half $(69.05 \%)$ of the members of SHGs had in medium change in monthly thrift habit categories, followed by 16.19 per cent and 14.76 per cent of them were in high and low change in monthly thrift habit category, respectively before participation in SHGs.

After participation in SHGs, more than two third $(78.57 \%)$ of the SHGs members had in medium change in monthly thrift habit categories, followed by 11.43 per cent and 10.00 per cent of them in from low and high change in monthly thrift habit category, respectively. The concept of microfinance rests on the premise that members will develop the habit of thrift before they can avail of loans. This, besides increasing the possibility of self reliance in meeting credit needs of the group members, will help efficiently deploy the credit among the members as their own money is at State. 
Table.1 Distribution of the members of SHGs according to their behavioural change before and after taking of microfinance

\begin{tabular}{|c|c|c|c|c|c|c|c|c|}
\hline \multirow[t]{2}{*}{$\begin{array}{l}\text { Sr. } \\
\text { No. }\end{array}$} & \multirow[t]{2}{*}{ Category } & \multirow[t]{2}{*}{ Score } & \multicolumn{2}{|c|}{$\begin{array}{c}\text { Before } \\
\text { participation } \\
(\mathbf{n}=\mathbf{2 1 0})\end{array}$} & \multirow[t]{2}{*}{ Score } & \multicolumn{2}{|c|}{$\begin{array}{c}\text { After } \\
\text { participation } \\
(\mathbf{n}=\mathbf{2 1 0})\end{array}$} & \multirow[t]{2}{*}{$\begin{array}{c}\text { 'Z' } \\
\text { value }\end{array}$} \\
\hline & & & No. & $\%$ & & No. & $\%$ & \\
\hline 1 & Low & Up to 13 & 34 & 16.19 & Up to 22 & 40 & 19.05 & \multirow[t]{6}{*}{$3.41 * *$} \\
\hline 2 & Medium & 14 to 17 & 138 & 65.71 & 23 to 29 & 91 & 43.33 & \\
\hline 3 & High & $18 \&$ above & 38 & 18.10 & $\begin{array}{c}30 \& \\
\text { above }\end{array}$ & 79 & 37.62 & \\
\hline & & Total & 210 & 100 & Total & 210 & 100 & \\
\hline & & Mean & \multicolumn{2}{|c|}{15.10} & Mean & \multicolumn{2}{|c|}{26.40} & \\
\hline & & S.D. & \multicolumn{2}{|c|}{2.83} & S.D. & \multicolumn{2}{|c|}{3.87} & \\
\hline
\end{tabular}

** Significant at 0.01 level of probability

Table.2 Distribution of the members of SHGs according to their impact of microfinance on behavioural change

\begin{tabular}{|c|c|c|c|c|}
\hline \multirow{2}{*}{ Sr. No. } & Category & \multirow{2}{*}{ Score } & \multicolumn{2}{|c|}{ Members of SHGs (n=210) } \\
\cline { 3 - 5 } & & & Frequency & Percentage \\
\hline $\mathbf{1}$ & Low & Up to 6 & 49 & 23.33 \\
\hline $\mathbf{2}$ & Medium & 7 to 16 & $\mathbf{1 2 5}$ & $\mathbf{5 9 . 5 2}$ \\
\hline $\mathbf{3}$ & High & $17 \&$ above & 36 & 17.14 \\
\hline & \multicolumn{2}{|c|}{ Total } \\
\hline \multicolumn{2}{|c|}{ Mean $=\mathbf{1 1 . 2 8}$} & 210 & 100.00 \\
\hline
\end{tabular}

Table.3 Distribution of the members of SHGs according to their social status change before and after taking of microfinance

\begin{tabular}{|c|c|c|c|c|c|c|c|c|}
\hline \multirow[t]{2}{*}{$\begin{array}{l}\text { Sr. } \\
\text { No. }\end{array}$} & \multirow[t]{2}{*}{ Category } & \multirow[t]{2}{*}{ Score } & \multicolumn{2}{|c|}{$\begin{array}{c}\text { Before } \\
\text { participation } \\
(\mathbf{n}=\mathbf{2 1 0})\end{array}$} & \multirow[t]{2}{*}{ Score } & \multicolumn{2}{|c|}{$\begin{array}{c}\text { After } \\
\text { participation } \\
(\mathbf{n}=\mathbf{2 1 0})\end{array}$} & \multirow[t]{2}{*}{$\begin{array}{c}\text { ' } Z \text { ' } \\
\text { value }\end{array}$} \\
\hline & & & No. & $\%$ & & No. & $\%$ & \\
\hline 1 & Low & Up to 8 & 70 & 33.33 & Up to 13 & 55 & 26.19 & \multirow[t]{6}{*}{3.36 **: } \\
\hline 2 & Medium & 9 & 100 & 47.62 & 14 to 17 & 89 & 42.38 & \\
\hline 3 & High & $\begin{array}{c}10 \& \\
\text { above }\end{array}$ & 40 & 19.05 & $18 \&$ above & 66 & 31.43 & \\
\hline & & Total & 210 & 100 & Total & 210 & 100 & \\
\hline & & Mean & \multicolumn{2}{|c|}{8.84} & Mean & \multicolumn{2}{|c|}{15.10} & \\
\hline & & S.D. & \multicolumn{2}{|c|}{1.07} & S.D. & \multicolumn{2}{|c|}{2.49} & \\
\hline
\end{tabular}

** Significant at 0.01 level of probability 
Table.4 Distribution of the members of SHGs according to their impact of microfinance on social status change

\begin{tabular}{|c|c|c|c|c|}
\hline \multirow{2}{*}{$\begin{array}{c}\text { Sr. } \\
\text { No. }\end{array}$} & Category & Score & \multicolumn{2}{|c|}{ Members of SHGs (n=210) } \\
\hline $\mathbf{1}$ & & & Frequency & Percentage \\
\hline $\mathbf{2}$ & Low & Up to 4 & 55 & 26.19 \\
\hline $\mathbf{3}$ & Medium & 5 to 8 & $\mathbf{9 9}$ & $\mathbf{4 7 . 1 4}$ \\
\hline \multicolumn{2}{r|}{ High } & 9 \& above & 56 & 26.67 \\
\hline \multicolumn{2}{|c|}{ Total } & 210 & 100.00 \\
\hline
\end{tabular}

Table.5 Distribution of the members of SHGs according to their change in annual expenditure pattern before and after taking of microfinance

\begin{tabular}{|c|c|c|c|c|c|c|c|c|}
\hline \multirow[t]{2}{*}{ Sr. No. } & \multirow[t]{2}{*}{ Category } & \multirow[t]{2}{*}{ Score } & \multicolumn{2}{|c|}{$\begin{array}{c}\text { Before } \\
\text { participation } \\
(\mathbf{n}=\mathbf{2 1 0})\end{array}$} & \multirow[t]{2}{*}{ Score } & \multicolumn{2}{|c|}{$\begin{array}{c}\text { After } \\
\text { participation } \\
(\mathbf{n}=\mathbf{2 1 0})\end{array}$} & \multirow[t]{2}{*}{$\begin{array}{c}\text { 'Z' } \\
\text { value }\end{array}$} \\
\hline & & & No. & $\%$ & & No. & $\%$ & \\
\hline 1 & Low & Up to 12 & 62 & 29.52 & Up to 19 & 54 & 25.71 & \multirow[t]{6}{*}{$2.71 * *$} \\
\hline 2 & Medium & 13 to 15 & 112 & 53.33 & 20 to 28 & 101 & 48.10 & \\
\hline 3 & High & $16 \&$ above & 36 & 17.15 & $29 \&$ above & 55 & 26.19 & \\
\hline & & Total & 210 & 100 & Total & 210 & 100 & \\
\hline & & Mean & \multicolumn{2}{|c|}{13.70} & Mean & \multicolumn{2}{|c|}{23.70} & \\
\hline & & S.D. & \multicolumn{2}{|c|}{2} & S.D. & \multicolumn{2}{|c|}{5.17} & \\
\hline
\end{tabular}

** Significant at 0.01 level of probability

Table.6 Distribution of the members of SHGs according to their impact of microfinance on change in annual expenditure pattern

\begin{tabular}{|c|c|c|c|c|}
\hline Sr. No. & Category & \multirow{2}{*}{ Score } & \multicolumn{2}{|c|}{ Members of SHGs (n=210) } \\
\cline { 3 - 5 } & & & Frequency & Percentage \\
\hline $\mathbf{1}$ & Low & Up to 4 & 48 & 22.86 \\
\hline $\mathbf{2}$ & Medium & 5 to 15 & $\mathbf{1 1 1}$ & $\mathbf{5 2 . 8 6}$ \\
\hline $\mathbf{3}$ & High & 16 above & 51 & 24.29 \\
\hline & \multicolumn{2}{r|}{ Total } \\
\hline \multicolumn{2}{r|}{ Mean $\mathbf{9 . 9 7}$} & 210 & 100.00 \\
\hline
\end{tabular}


Table.7 Distribution of the members of SHGs according to their change in assets before and after taking of microfinance

\begin{tabular}{|c|c|c|c|c|c|c|c|c|}
\hline \multirow[t]{2}{*}{$\begin{array}{l}\text { Sr. } \\
\text { No. }\end{array}$} & \multirow[t]{2}{*}{ Category } & \multirow[t]{2}{*}{ Score } & \multicolumn{2}{|c|}{$\begin{array}{c}\text { Before } \\
\text { participation } \\
(\mathbf{n}=\mathbf{2 1 0})\end{array}$} & \multirow[t]{2}{*}{ Score } & \multicolumn{2}{|c|}{$\begin{array}{c}\text { After } \\
\text { participation } \\
(\mathbf{n}=\mathbf{2 1 0 0}\end{array}$} & $\begin{array}{c}\text { 'Z' } \\
\text { Value }\end{array}$ \\
\hline & & & No. & $\%$ & & No. & $\%$ & \multirow[t]{7}{*}{$2.06 *$} \\
\hline $\mathbf{1}$ & Low & Up to 9 & 44 & 20.95 & Up to 13 & 40 & 19.05 & \\
\hline 2 & Medium & 10 to 11 & 140 & 66.67 & 14 to 17 & 119 & 56.67 & \\
\hline 3 & High & $\begin{array}{c}12 \& \\
\text { above }\end{array}$ & 26 & 12.38 & $18 \&$ above & 51 & 24.29 & \\
\hline & & Total & 210 & 100 & Total & 210 & 100 & \\
\hline & & Mean & \multicolumn{2}{|c|}{10.40} & Mean & \multicolumn{2}{|c|}{15.10} & \\
\hline & & S.D. & \multicolumn{2}{|c|}{1.48} & S.D. & \multicolumn{2}{|c|}{2.88} & \\
\hline
\end{tabular}

* Significant at 0.05 level of probability

Table.8 Distribution of the members of SHGs according to their impact of microfinance on change in asset

\begin{tabular}{|c|c|c|c|c|}
\hline Sr. No. & Category & \multirow{2}{*}{ Score } & \multicolumn{2}{c|}{ Members of SHGs (n=210) } \\
\cline { 3 - 5 } & & & Frequency & Percentage \\
\hline $\mathbf{1}$ & Low & Up to 1 & 51 & 24.29 \\
\hline $\mathbf{2}$ & Medium & 2 to 7 & $\mathbf{1 0 3}$ & $\mathbf{4 9 . 0 5}$ \\
\hline $\mathbf{3}$ & High & 8 \& above & 56 & 26.67 \\
\hline \multicolumn{2}{|c|}{ Total } & 210 & 100.00 \\
\hline
\end{tabular}

Table.9 Distribution of the members of SHGs according to their change in annual income before and after taking of microfinance

\begin{tabular}{|c|c|c|c|c|c|c|c|c|}
\hline \multirow[t]{2}{*}{$\begin{array}{l}\text { Sr. } \\
\text { No. }\end{array}$} & \multirow[t]{2}{*}{ Category } & \multirow[t]{2}{*}{ Score } & \multicolumn{2}{|c|}{$\begin{array}{c}\text { Before } \\
\text { participation } \\
(\mathbf{n}=\mathbf{2 1 0})\end{array}$} & \multirow[t]{2}{*}{ Score } & \multicolumn{2}{|c|}{$\begin{array}{c}\text { After } \\
\text { participation } \\
(\mathbf{n}=\mathbf{2 1 0})\end{array}$} & \multirow[t]{2}{*}{$\begin{array}{c}\text { ' } Z \text { ' } \\
\text { value }\end{array}$} \\
\hline & & & No. & $\%$ & & No. & $\%$ & \\
\hline 1 & Low & Up to 11 & 68 & 32.38 & Up to 15 & 26 & 12.38 & \multirow[t]{6}{*}{$2.69 * *$} \\
\hline 2 & Medium & 12 to 13 & 101 & 48.10 & 16 to 21 & 137 & 65.24 & \\
\hline 3 & High & $14 \&$ above & 41 & 19.52 & $\begin{array}{l}22 \& \\
\text { above }\end{array}$ & 47 & 22.38 & \\
\hline & & Total & 210 & 100 & Total & 163 & 100 & \\
\hline & & Mean & \multicolumn{2}{|c|}{12.16} & Mean & \multicolumn{2}{|c|}{18.80} & \\
\hline & & S.D. & \multicolumn{2}{|c|}{1.58} & S.D. & \multicolumn{2}{|c|}{3.19} & \\
\hline
\end{tabular}

** Significant at 0.01 level of probability 
Table.10 Distribution of the members of SHGs according to their impact microfinance on change in annual income

\begin{tabular}{|c|c|c|c|c|}
\hline Sr. No. & Category & Score & \multicolumn{2}{|c|}{ Members of SHGs (n=210) } \\
\hline $\mathbf{1}$ & Low & Up to 3 & 30 & 14.29 \\
\hline $\mathbf{2}$ & Medium & 4 to 9 & $\mathbf{1 3 8}$ & $\mathbf{6 5 . 7 1}$ \\
\hline $\mathbf{3}$ & High & 10 \& above & 42 & 20.00 \\
\hline \multicolumn{2}{r|}{ Total } & 210 & 100.00 \\
\hline & Mean $=\mathbf{6 . 6 1}$ & S.D. $=\mathbf{3 . 4 5}$ & \\
\hline
\end{tabular}

Table.11 Distribution of the members of SHGs according to their change in borrowing pattern before and after taking of microfinance

\begin{tabular}{|c|c|c|c|c|c|c|c|c|}
\hline \multirow[t]{2}{*}{$\begin{array}{l}\text { Sr. } \\
\text { No. }\end{array}$} & \multirow[t]{2}{*}{ Category } & \multirow[t]{2}{*}{ Score } & \multicolumn{2}{|c|}{$\begin{array}{c}\text { Before } \\
\text { participation } \\
(\mathbf{n}=\mathbf{2 1 0})\end{array}$} & \multirow[t]{2}{*}{ Score } & \multicolumn{2}{|c|}{$\begin{array}{c}\text { After } \\
\text { participation } \\
(\mathbf{n}=\mathbf{2 1 0})\end{array}$} & $\begin{array}{c}\text { 'Z' } \\
\text { value }\end{array}$ \\
\hline & & & No. & $\%$ & & No. & $\%$ & \multirow[t]{7}{*}{$2.74 * *$} \\
\hline 1 & Low & Up to 8 & 72 & 34.29 & Up to 10 & 80 & 38.10 & \\
\hline 2 & Medium & 9 & 121 & 57.62 & 11 to 12 & 106 & 50.48 & \\
\hline 3 & High & $10 \&$ above & 17 & 8.10 & $13 \&$ above & 24 & 11.42 & \\
\hline & & Total & 210 & 100 & Total & 210 & 100 & \\
\hline & & Mean & \multicolumn{2}{|c|}{8.27} & Mean & \multicolumn{2}{|c|}{11.21} & \\
\hline & & S.D. & \multicolumn{2}{|c|}{0.96} & S.D. & \multicolumn{2}{|c|}{1.21} & \\
\hline
\end{tabular}

** Significant at 0.01 level of probability

Table.12 Distribution of the members of SHGs according to their impact of microfinance on change in borrowing pattern

\begin{tabular}{|c|c|c|c|c|}
\hline Sr. No. & Category & \multirow{2}{*}{ Score } & \multicolumn{2}{|c|}{ Members of SHGs (n=210) } \\
\cline { 3 - 4 } & & & Frequency & Percentage \\
\hline $\mathbf{1}$ & Low & Up to 2 & 74 & 35.24 \\
\hline $\mathbf{2}$ & Medium & 3 & $\mathbf{7 8}$ & $\mathbf{3 7 . 1 4}$ \\
\hline $\mathbf{3}$ & High \& above & 58 & 27.62 \\
\hline & Total & 210 & 100.00 \\
\hline
\end{tabular}


Table.13 Distribution of the members of SHGs according to their change in employment status before and after taking of microfinance

\begin{tabular}{|c|c|c|c|c|c|c|c|c|}
\hline \multirow[t]{2}{*}{$\begin{array}{l}\text { Sr. } \\
\text { No. }\end{array}$} & \multirow[t]{2}{*}{ Category } & \multirow[t]{2}{*}{ Score } & \multicolumn{2}{|c|}{$\begin{array}{c}\text { Before } \\
\text { participation } \\
(\mathbf{n}=\mathbf{2 1 0})\end{array}$} & \multirow[t]{2}{*}{ Score } & \multicolumn{2}{|c|}{$\begin{array}{c}\text { After } \\
\text { participation } \\
(\mathbf{n}=\mathbf{2 1 0})\end{array}$} & \multirow[t]{2}{*}{$\begin{array}{c}\text { 'Z' } \\
\text { value }\end{array}$} \\
\hline & & & No. & $\%$ & & No. & $\%$ & \\
\hline 1 & Low & Up to 8 & 86 & 40.95 & Up to 13 & 43 & 20.48 & \multirow[t]{6}{*}{$3.02 * *$} \\
\hline 2 & Medium & 9 to 10 & 91 & 43.33 & 14 to 17 & 113 & 53.81 & \\
\hline 3 & High & $\begin{array}{c}11 \& \\
\text { above }\end{array}$ & 33 & 15.72 & $\begin{array}{c}18 \& \\
\text { above }\end{array}$ & 54 & 25.71 & \\
\hline & & Total & 210 & 100 & Total & 210 & 100 & \\
\hline & & Mean & \multicolumn{2}{|c|}{8.80} & Mean & \multicolumn{2}{|c|}{15.08} & \\
\hline & & S.D. & \multicolumn{2}{|c|}{1.66} & S.D. & \multicolumn{2}{|c|}{2.51} & \\
\hline
\end{tabular}

** Significant at 0.01 level of probability

Table.14 Distribution of the members of SHGs according to their impact of microfinance on change in employment status

\begin{tabular}{|c|c|c|c|c|}
\hline \multirow{2}{*}{ Sr. No. } & Category & \multirow{2}{*}{ Score } & \multicolumn{2}{|c|}{ Members of SHGs $(\mathbf{n}=\mathbf{2 1 0})$} \\
\cline { 4 - 5 } & & & Frequency & Percentage \\
\hline $\mathbf{1}$ & Low & Up to 4 & 42 & 20.00 \\
\hline $\mathbf{2}$ & Medium & 5 to 9 & $\mathbf{1 1 5}$ & $\mathbf{5 4 . 7 6}$ \\
\hline $\mathbf{3}$ & High & 10 above & 53 & 25.24 \\
\hline \multicolumn{2}{r|}{ Total } & 210 & 100.00 \\
\hline
\end{tabular}

Table.15 Distribution of the members of SHGs according to their change in monthly thrift habit before and after taking of microfinance

\begin{tabular}{|c|c|c|c|c|c|c|c|c|}
\hline \multirow[t]{2}{*}{$\begin{array}{l}\text { Sr. } \\
\text { No. }\end{array}$} & \multirow[t]{2}{*}{ Category } & \multirow[t]{2}{*}{ Score } & \multicolumn{2}{|c|}{$\begin{array}{c}\text { Before } \\
\text { participation } \\
(\mathbf{n}=\mathbf{2 1 0})\end{array}$} & \multirow[t]{2}{*}{ Score } & \multicolumn{2}{|c|}{$\begin{array}{c}\text { After } \\
\text { participation } \\
(\mathbf{n}=\mathbf{2 1 0})\end{array}$} & \multirow[t]{2}{*}{$\begin{array}{c}\text { ' } Z \text { ' } \\
\text { value }\end{array}$} \\
\hline & & & No. & $\%$ & & No. & $\%$ & \\
\hline 1 & Low & Up to 10 & 31 & 14.76 & Up to 14 & 24 & 11.43 & \multirow[t]{6}{*}{$2.71 * *$} \\
\hline 2 & Medium & 11 to 12 & 145 & 69.05 & 15 to 17 & 165 & $\mathbf{7 8 . 5 7}$ & \\
\hline 3 & High & $13 \&$ above & 34 & 16.19 & $\begin{array}{c}18 \& \\
\text { above }\end{array}$ & 21 & 10 & \\
\hline & & Total & 210 & 100 & Total & 210 & 100 & \\
\hline & & Mean & \multicolumn{2}{|c|}{10.95} & Mean & \multicolumn{2}{|c|}{15.65} & \\
\hline & & S.D. & \multicolumn{2}{|c|}{1.54} & S.D. & \multicolumn{2}{|c|}{1.99} & \\
\hline
\end{tabular}

** Significant at 0.01 level of probability 
Table.16 Distribution of the members of SHGs according to their impact of microfinance on change in monthly thrift habit

\begin{tabular}{|c|c|c|c|c|}
\hline \multirow{2}{*}{ Sr. No. } & Category & \multirow{2}{*}{ Score } & \multicolumn{2}{|c|}{ Members of SHGs (n=210) } \\
\cline { 3 - 5 } & & & Frequency & Percentage \\
\hline $\mathbf{1}$ & Low & Up to 3 & 37 & 17.62 \\
\hline $\mathbf{2}$ & Medium & 4 to 7 & $\mathbf{1 3 5}$ & $\mathbf{6 4 . 2 9}$ \\
\hline $\mathbf{3}$ & High & 8 \& above & 38 & 18.10 \\
\hline \multicolumn{2}{|c}{ Total } & 210 & 100.00 \\
\hline
\end{tabular}

Table.17 Distribution of the members of SHGs according to their overall impact of microfinance

\begin{tabular}{|c|c|c|c|c|c|}
\hline \multirow[t]{3}{*}{ Sr. No. } & \multirow[t]{3}{*}{ Enterprise } & \multicolumn{3}{|c|}{ Category } & \multirow{3}{*}{$\begin{array}{c}\text { Total } \\
(\mathbf{n}=\mathbf{2 1 0})\end{array}$} \\
\hline & & Low & Medium & High & \\
\hline & & Up to 26 & 27 to 72 & 73 and above & \\
\hline 1 & Sewing & $3(6.20)$ & $35(73.00)$ & $10(20.80)$ & $48(100)$ \\
\hline 2 & Processing & $4(14.80)$ & $15(55.60)$ & $8(29.60)$ & $27(100)$ \\
\hline 3 & Agri. & $5(12.20)$ & $27(65.80)$ & $9(22.00)$ & $41(100)$ \\
\hline 4 & AHD & $2(6.90)$ & 23 (79.30) & $4(13.80)$ & $29(100)$ \\
\hline 5 & Other business & $9(36.00)$ & $10(40.00)$ & $6(24.00)$ & $25(100)$ \\
\hline 6 & Labour & $6(15.00)$ & $27(67.50)$ & $7(17.50)$ & $40(100)$ \\
\hline \multicolumn{2}{|c|}{ Average Overall Impact } & $29(13.81)$ & $137(65.24)$ & $44(20.95)$ & $210(100)$ \\
\hline \multicolumn{3}{|c|}{ Mean $=49.45$} & & .D. $=23.50$ & \\
\hline
\end{tabular}

In this part, change in thrift in terms of rupees and measured in terms of difference in thrift before and after participation in SHGs.

Calculated ' $Z$ ' value 2.71 from table 15 was found significant at 1 per cent level of probability indicating that there existed a significant difference in change in monthly thrift habit of SHGs members before and after participation in SHGs. It could therefore, be stated that the SHGs members differed significantly in their change in monthly thrift habit before and after participation in SHGs. It means that SHGs is helpful to the members of SHGs for increase their change in monthly thrift habit.

SHG members could able to save monthly and so they could not have to depend on other money lenders and agency.SHG members could actively participate in the financial activities and could sustain it for longer period. SHG helped the members not to expend unnecessarily.

It was observed form the table 16 that, after participation of SHGs, more than half (64.29\%) of members of SHGs had medium change in monthly thrift habit category, followed by 18.10 per cent and 17.62 per cent of the SHGs members had high and low change in monthly thrift habit category, respectively. It was observed from above table that, most of the members of SHGs having medium impact of microfinance on change in monthly thrift habit. 
The mean monthly thrift scores of before and after participation in SHGs differed significantly with ' $Z$ ' value (2.71) at 1 per cent level of probability implying that there was an improvement in the monthly thrift habit of members of SHGs due to participation in SHGs.

The observations of the present study are in accordance with the findings of, Borbora et al., (2001), Katole (2001), Nedumaran, et al., (2001), Puhazhendi and Satyasai (2001), Banerjee (2002), Mohite (2003) and Rewale (2003).

\section{Overall impact}

It was observed from the table 17 that, after participation in SHGs, more than half (65.24\%) of members of SHGs had medium overall impact, followed by 20.95 per cent and 13.81 per cent of the SHGs members had high and low overall impact category, respectively. It was observed from above table that, most of the members of SHGs having medium overall impact of microfinance on its members of SHGs.

Thus, it is concluded that a majority of the members of SHGs had medium level of impact of microfinance and brought out that highest change in impact parameters was noticed with AHD groups $(79.30 \%)$ followed by sewing groups

(73.00\%), Labours (67.50\%), Agriculture $(65.80 \%)$, processing $(55.60 \%)$ and other groups $(40.00 \%)$ respectively.

The objective of the SHGs provides employment and brings the members of SHGs above poverty line by increasing their annual income. Hence there may be the medium impact of microfinance on socio-economic condition of majority of members of SHGs.
This finding was in agreement with the findings of Mohammad (2008), Jatav et al., (2010), Kale (2012), Bansode et al., (2013), Mankar et al., (2013), Bhandari (2014), Adsul (2016) and Dhulgand (2020).

It was concluded from the result after comparing the participation of SHGs members as well calculating the $Z$ value of each dimension it clearly showed that after actively participation in SHGs the women got the benefit through microfinance in every aspect of their life. Hence it was concluded that a majority of the members of SHGs had medium level of impact of microfinance and brought out that highest change in impact parameters was noticed with AHD groups (79.30\%).

\section{References}

Adsul, Archana H. (2004). Case studies of self-help units under SGSY of Gramin Mahila Va Balak Vikas Mandal of Bank of Maharashtra in Pune district. M.Sc. (Agri.) Thesis (Maharashtra), Mahatma Phule Krishi Vidyapeeth, Rahuri.

Adsul, G. B. (2016). Socio-economic impact of National Horticulture Mission on its beneficiaries in Marathwada region. Ph.D. (Agri.) Thesis, Vasantrao Naik Marathwada Krishi Vidyapeeth, Parbhani (Maharashtra)

Banerjee, G. D. (2002). Evaluation study on self-help group. Financing Agriculture - An In House Journal of Agricultural Finance Corporation Ltd. 34 (2): 3840.

Bansode, S. M., G. S. Ankush, J. V. Mande and D. D. Suradkar (2013).Impact of Self Help Group on socio-economic development of their members. Journal of Community Mobilization on Sustainable Development 8 (11), pp: 117-120. 
Bhandari, S. D. (2014). Impact of Mahatma Gandhi national rural employment guarantee act on the beneficiaries. M.Sc. (Agri.) Thesis, Vasantrao Naik Marathwada Krishi Vidyapeeth, Parbhani (Maharashtra).

Borbora, Saundarjya and Mahanta, Ratul (2001). Microfinance through self help groups and its impact: A case of Rashtriya Gram Vikas Nidhi Credit and Saving Programme in Assam. Indian Journal of Agricultural Economics 56(3): 449 - 450.

Dahiya, Prem Singh; Pandey, N. K. and Karol, Anshuman (2001). Socio-economic evaluation of self-help groups in Solan district of Himachal Pradesh: Impact, issues and policy implications. Indian Journal of Agricultural Economics 56(3): 486-487.

Dhulgand, V. G. (2020). Socio-economic impact of Mahatma Gandhi National Rural Employment Guarantee act on its beneficiaries in Marathwada region. Ph.D. (Agri.) Thesis, Vasantrao Naik Marathwada Krishi Vidyapeeth, Parbhani (Maharashtra).

Edwards, M. M. (2000). Community guide to development impact analysis. UWMadison program on agricultural technology studies, pp: 315-319.

Gangaiah, C., B. Nagaraja and C. Vasudevulu Naidu (2006). Impact of SHGs on income and employment: A case study. Kurukshetra, 54(5): 18-23.

Jatav, H., M. M. Patel, K. S. Kumarand and A. Saxena, (2010).Impact of front line demonstrations on scientific temperament of wheat growers. Raj. $J$. Ext. Edu. (17), pp: 14-16.

Kale, M. G. (2012).Impact of Swarnjaynti Gram Swarojgar Yojana on socioeconomic condition \& beneficiaries. M.Sc. (Agri.) Thesis, Marathwada Krishi Vidyapeeth, Parbhani (Maharashtra).
Katole, A. S. (2001). Impact of self help group on socio-economic development of its women member M.Sc. (Agri.) Thesis, Dr. Panjabrao Deshmukh Krishi Vidyapeeth, Akola (Maharashtra).

Kulkarni, N. M. (2003). A study of beneficiary women of self help group organized by Jana Prabodhini with special referee to their socio-economic development. M.Sc. (Agri.) Thesis, Mahatma Phule Krishi Vidyapeeth, Rahuri (Maharashtra).

Mankar, D. M., P. P. Wankhade and Y. B. Shambharkar (2013).Impact of National Horticulture Mission on its beneficiaries. International Journal of Extn.Edu. (9), pp: 72-80.

Mishra, S. N. and Hossain, M. M. (2001).A study on the working and impact of Dharmadevi Mahila Mandal - A rural self-help group in Kalahandi district of Orissa. Indian Journal of Agricultural Economics 56(3): 480-481.

Mohammad, A. (2008). Impact of social forestry programme in Baramula of Kashmir valley. Indian Res. J. Ext. Edu. 8 (1), pp: 22-24.

Mohite, D. P. (2003). Performance of self-help groups in Ratnagiri district - an economic analysis. M.Sc. (Agri.) Thesis, Dr. Balasaheb Sawant Konkan Krishi Vidyapeeth, Dapoli.

Nedumaran, S., Palanisami, K. and Swaminathan, L. P. (2001). Performance and impact of SHGs in Tamil Nadu. Indian Journal of Agricultural Economics 56(3): 471472.

Peerzade, S. A. and Prema Parande (2005). Employment of women: A study. Kurukshetra, 54(1): 7-11.

Puhazhendhi, V. (2000).Evaluation study of SHGs in Tamil Nadu, NABARD, Mumbai.

Puhazhendhi, V. and Satyasai, K.J.S. (2000). Micro finance for rural people: An impact evaluation. National Bank for 
Agricultural and Rural Development, Mumbai.

Rewale, Rajani A. (2003). A study on women's self-help groups engaged in agricultural activities in Ratnagiri district. M.Sc. (Agri.) Thesis, Dr. Balasaheb Sawant Konkan Krishi Vidyapeeth, Dapoli.

Sarker, Debnaryan (2001). A study on SHGNGO and SHG-Non-NGO models of rural micro financing in West Bengal. Indian Journal of Agricultural Economics56 (3): 454-456.

Singh, D. K. (2001). Impact of SHGs on the economy of marginalized farmers of Kanpur Dehat district of Uttar Pradesh (A case study).Indian Journal of Agricultural Economics 56(3): 463-
464.

Singh. B. and R. B. Prasad (2000). Effect of IRDP on socio-economic status of beneficiaries. Maharashtra Journal of Extension Education.19: 164-167.

Topare, Dipali (2006). Impact on employment generation and income of women members of self help groups. M.Sc.(Agri). Thesis, Dr. Balasaheb Sawant Konkan Krishi Vidyapeeth, Dapoli.

Yadav, L., Varma, S., Jayanti, Neetima and Vandana (2000). Impact of women Group: A study. Abstract: National Seminar on 'Participatory approach in rural development' at MAU, Parbhani on February 27 -28, 2006.

\section{How to cite this article:}

Nair, R. G., R. P. Kadam and Kapse, P. S. 2021. Socio-Economic Impact of Microfinance on the SHGS Members Engaged in Agriculture and Allied Enterprises. Int.J.Curr.Microbiol.App.Sci. 10(05): 784-801. doi: https://doi.org/10.20546/ijcmas.2021.1005.089 